\title{
Online Training: An Alternative Solution of the Empowerment for Parents of Children with Autism
}

\author{
Herlina $^{1 *}$, Rudi Susilana ${ }^{2}$ ic \\ ${ }^{1}$ Psychology Department, Universitas Pendidikan Indonesia, Bandung, Indonesia \\ ${ }^{2}$ Curriculum and Educational Technology Department, Universitas Pendidikan Indonesia, Bandung, Indonesia \\ e-mail: herlinahasan_psi@upi.edu
}

\section{A R T I C L E I N F O}

Article history:

Received Maret 13, 2021

Revised April 11, 2021

Accepted May 05, 2021

Available online May 25, 2021

Kata Kunci:

Autisme, Program Intervensi Mandiri

Keywords:

Autism, Independent

Intervention Program

\begin{abstract}
A B S T R A K
Orang tua perlu memahami betapa pentingnya memberikan tindakan yang tepat dalam menangani anak autis. Upaya tersebut dapat dilakukan dengan teknik pendekatan intervensi, namun beberapa orang tua sering mengalami kesulitan dalam melakukan upaya tersebut. Salah satu solusi untuk mengatasi permasalahan ini adalah dengan membentuk Program Pelatihan Online Intervensi Mandiri (PIM). Penelitian ini bertujuan untuk membuktikan bahwa Pelatihan Online Program Intervensi Mandiri (PIM) merupakan cara yang efektif untuk memberdayakan orang tua dalam menangani anak autis. Penelitian dilakukan melalui uji coba lapangan yang melibatkan 11 orang tua anak penyandang autisme di kota di Indonesia. Subjek diberikan Pelatihan PIM Online dengan platform seperti Zoom, Website, dan WhatsApp. Data efektivitas pelatihan dilihat dari hasil evaluasi diri peserta sebelum dan sesudah pelatihan. Hasil penelitian menunjukkan bahwa setelah mengikuti Pelatihan PIM Online, orang tua merasa mereka lebih baik dalam memahami konsep tentang Autism Spectrum Disorder (ASD), keterampilan sosial, intervensi, dan program intervensi individu, serta keterampilan merancang program intervensi untuk anak-anak penyandang disabilitas. autisme, dibandingkan dengan kondisi sebelum mengikuti pelatihan. Berdasarkan hasil tersebut, Pelatihan PIM Online diharapkan dapat menjadi solusi yang tepat untuk memberdayakan orang tua dalam merancang program intervensi keterampilan social bagi anak autis, tanpa Batasan waktu, tempat, dan biaya.
\end{abstract}

\section{A B S T R A C T}

Parents need to understand how important it is to provide proper treatment in dealing with children with autism. The effort is with an intervention approach technique, but some parents often experience difficulties in making intervention efforts. One solution to the problem that can be done is by establishing the Independent Intervention Program Online Training (PIM). This study aims to prove that the Independent Intervention Program Online Training or PIM is an effective way to empower parents in dealing with children with autism. The research was conducted through field trials involving 11 parents of children with autism from a number of cities in Indonesia. Subjects were provided PIM Online Training by platforms such as Zoom, Website, and WhatsApp. Training effectiveness data is seen from the results of the subject's self-evaluation before and after training. The results showed that after participating in the PIM Online Training, parents saw themselves better in understanding the concept of Autism Spectrum Disorder (ASD), social skills, intervention, and individual intervention programs, as well as skills in designing intervention programs for children with disabilities. autism, compared to pre-training conditions. Based on these results, PIM Online Training is expected to be the right solution to empower parents in designing social skills intervention programs for children with autism, without limitation of time, place and cost.

This is an open access article under the CC BY-SA license.

Copyright (c) 2021 by Author. Published by Universitas Pendidikan Ganesha

\section{INTRODUCTION}

A number of studies have shown that parental involvement in handling children with autism plays an important role in the success of the intervention (Negri \& Castorina, 2014; Elder, 2013). In addition, stated that parental involvement is not only effective, but also efficient and cost-wise (Rudy, 2013). In general, parents give their children feeling of safe and protection both mental and physical aspects. No matter what the condition and situation, they stand out for them by unconditional love and affection as well those in disabilities especially with autism. Parents need to understand how to deal with children with autism because the role of parents in assisting children with special needs or specifically for children with autism is very essential to help them gaining optimum development (Primasari \& Supena, 2020). The role of parents crucial in early intervention for children 
with autism (Rafikayati \& Jauhari, 2018). Parental-mediated interventions have been shown to be effective in reducing the severity of autism (Oono et al., 2013). In addition, the accuracy of parental intervention and the use of children' spontaneous language increase the implementation of intervention techniques (Ingersoll \& Wainer, 2013).

In fact, it is still found parents who lack of information, understanding, and knowledge in how to give proper treatment to them. It leads to mental pressure or stress for parents to face typical situation. They often still need support from surroundings (Putri et al., 2019). By being able to manage stress and be realistic for expectations, it affects much on their psychological condition (Kurniadi et al., 2019) and results to reciprocity and negative impact on their children both in direct and long-term effects (Karst \& Van Hecke, 2012). Based on the explanations above, there are types of interventions that can be carried out, depending on the type, the benefits and targets of intervention mediation carried out by parents to children with autism lead to different results (Kasari et al., 2015). On the other hand, some parents also consider that children with autism contributing them much for suitable treatment about coping strategies, including acceptance, proactive thinking, character growth, spirituality, and parental support networks, encouraging welfare (Ilias et al., 2017). Based on the taken data, it was found that many parents did not have the knowledge, skills or financial ability to handle their children with autism. Interview was conducted with ABA Speech Therapy Training participants at Isola Resort for collecting the data. It was exposed that the high cost of therapy tends to be the main obstacle for parents to given them needed treatment including the availability of time and energy for intervention. Those aspects as mentioned above contribute to parents' barriers to get along with their autism children.

In order to handle the children effectively, parents need an adequate capacity (Dunst et al., 2014). This implies that empowerment is necessary for the parents to be able to handle their children at home. According to Turnbull et al. (Murray et al., 2013), empowerment is a process including the improvement of one's knowledge, skill, and motivation to achieve the desired result, and refers to an experience continuum providing an opportunity for an individual to use their competence to learn new information and skills. In regard to the present study, the term "empowerment" is related to an attempt to improve parents' knowledge, motivation, expectation, and skill in performing the social skills intervention on their children with autism. Parents' understanding in how to give proper treatment for children with autism is absolutely vital. This can help to improve their development if parents have competence about knowledge and skills and how to intervene in children with autism (Yuwono et al., 2020). The less information or knowledge about children with autism will lead to inadequate handling or treatment. Therefore, information sharing and special training can help the process of transfer knowledge and its dissemination (Irvan, 2016). These trainings are seen to be necessary given to parents who have children with autism. There will be differences in results between interventions that are mediated by the parents themselves and the assistance of a therapist. Therapist-assisted intervention in children with autism will have a greater advantage. If the intervention is carried out by the parents themselves, it requires more training to get the same benefits as those assisted by a therapist (Ingersoll et al., 2016).

As an effort for parents' empowerment, a number of training has been provided for them to perform intervention on their children at home (Autism Ontario, 2012). Through the training, parents obtain numerous benefits, including: 1) Increase the ability in implementing the newly-learnt strategies (Beaudoin et al., 2014); 2) increase the confidence and understanding regarding the organization of children's behaviour (Pillay et al., 2011); and 3) increase an active role in the process of educating and decision-making for their children, parents' involvement in the activities creating societal changes, and rising expectation on the children's improvement (Murray et al., 2013). However, not all parents were able to receive the given training easily. According to Kolb (2007), in general, there are several disadvantages of trainings considered as obstacles for the parents. The disadvantages consist of 1) transportation issue, due to the distance between the parents' residence and the training venue; 2) training schedule and parents' leisure time not matching; 3) difficulties in looking after the children when parents are on training, and 4) high training cost.

Lecturing parents to be able to give adequate treatment for children with autism is still feasible. The trainings are held to increase parental understanding to do with them. Some of them discuss nutrition for autistic children who are often neglected by both parents and teachers (Iswari et al., 2019). Doing activities to socialize with surrounding environment is needed because of the knowledge limitations. Besides, there are some aspects to be considered regarding the form of programs to teach parents to handle children with autism (Steiner et al., 2012). Parents by children with autism can learn accurately in how to use online programs determined and directed by themselves to obtain information support and training about related topics (Suppo \& Mayton, 2014). By providing training to meet their needs and tailored with the elements of certain families, it will have a positive impact on parents when they intervene them (Booth et al., 2018). Parents training can be interpreted as an effort to improve their ability to have a positive attitude which can have an influence on their children development. It includes teaching parents about skills related to managing their own emotions, cognition and behaviour (Steiner et al., 2012). The autistic children have an important role and refer to impact on the outcome of treatment for them. Tthe training program for parents by children with autism includes how the program is 
implemented, targeted skills and an evaluation of training activities systematically (Schultz et al., 2011). Training for parents of children with autism are usually done by providing intervention training to the child's mother. It is conducted one-on-one for approximately 2.5 to 25 hours (Patterson et al., 2012). During the training period, parents need to report how problems occur to children (Kuravackel et al., 2018). Based on the performed offline training through the Independent Intervention Program (Program Intervensi Mandiri or PIM), , it was found the disadvantages as mentioned previously (Kolb, 2007). PIM is a training program, enabling parents to design and independently perform social skills intervention on their children with autism. Despite the offline program, PIM has been designed with minimal cost, some participants were not able to complete the training. they faced some obstacles including the absence of any individuals as to look after their children while the parents are on the training, as well as bad weather (heavy rain).

The rapid development of technology and information can be utilized by people as a medium to simplify a work or activity by easy access anywhere and anytime. The use of this technology can be applied to help parents with children with Autism Spectrum Disorder (ASD) for better treatment with expert assistance through online training activities. In supporting point of view, online training can greatly reduce the cost of parental training practices and expand the participants. It is also substantial to overview before implementing the online training programs such as the structure and organization of learning units, audience heterogeneity, technology literacy, participation of facilitators (Zorzi \& Marzano, 2020). The impact of digital technology also affects the parents' stress level (Allen \& Shane, 2014). In other studies, it has been shown that online training programs have impacts to others, including: (1) decreasing parental stress, (2) increasing relevant knowledge, (3) increasing children's prosocial behaviour, (4) decreasing hyperactive behaviour, and (5) the level of high satisfaction with the intervention (Pennefather et al., 2018). Moreover, online training may be a cost-effective way to increase one's understanding and acceptance of other people with autism (Patricia et al., 2015). It is also stated that regarding to the advantages of online training, delivering such training online can partially ease the burden on families and head to increasing participation and results. Parents' completion on interactive online training and participate in hands-on sessions to demonstrate the skills being trained are seen as the key factors (Douglas et al., 2017).

From the explanation above, online training is described as a solution. It appears to be more flexible in terms of time, place, and cost. It is hoped that it can also add insight to parents in treating children with autism. The online training program that has been held is the Independent Intervention Training Program (PIM) as a form of online training program using website-based technology which contains training teaching materials in various forms (Susilana et al., 2020) and in the future, existing materials The website will also continue to grow with validation by experts (Tirtayani et al., 2017). Based on the development of information technology, it has given opportunities for individuals to access information from anywhere, any time as efficient as possible. In relation to the training for parents, trainings received through the internet are assumed to be prospective and potential for parents, as well as low cost for parents and trainers (Kolb, 2007). Referring to the disadvantage and the advantage of online trainings (Kolb, 2007), as well as the observed offline PIM trainings, it can be assumed that it can minimize the aforementioned disadvantages. On that account, the present study was conducted to test the effectiveness of the online Program Intervensi Mandiri (PIM) training in empowering the parents of the children with autism.

\section{METHOD}

The study was conducted using pre-test-post-test field experiment design. The treatment was in the form of Program Intervensi Mandiri (PIM) online training given via platforms such as Zoom and WhatsApp. PIM comprised two steps of activity. The first step was giving the conceptual materials and workshop. The conceptual materials included theoretical concepts regarding Autism Spectrum Disorder (ASD), social skills, intervention, and individual intervention program. The workshop was done in the form of filling the Social Skills-Individualized Intervention Program (SS-IIP) for. SS-IIP was a social skill intervention program plan or draft completed by parents as a reference to implement the intervention on their children. After completed or filled, the SS-IIP form was sent by the subjects to the training team through e-mail to review. Subjects were given a certain amount of time to learn the materials and finish the workshop tasks. All materials, either conceptual or SS-IIP were accessible from the provided website. The second step was the implementation of intervention by the parents on their children. The intervention was performed by parents in accordance with the SS-IIP planned or arranged by the parents themselves. Before and after receiving each training material and workshop, as well as implementing the intervention, subjects were asked to complete the self-evaluation questionnaire.

The present study employed 11 participants. Subjects were obtained through the flyer shared via WhatsApp, Instagram, and Facebook. Meanwhile, registration form and form stating subject's readiness/commitment to participate in the whole training process were provided in the format of Google form. 
Subjects were selected purposively by choosing ones who 1) are parents of children with ASD, and 2) expressed their commitment to participate in the whole PIM Online Training. Instruments used in the study were questionnaires regarding subjects' comprehension on the training materials. The questionnaire was a selfevaluation one, filled by the subjects before and after receiving the training materials. Subjects' score range from 1 to 9, with 1-3 categorized as "low/bad", 4-6 as "medium/decent", and 7-9 as "high/good".

Table 1. PIM Online Training Instrument Grid

\begin{tabular}{|c|c|}
\hline Number & Dimensions and Aspects \\
\hline 1 & $\begin{array}{l}\text { Autism Spectrum Disorder (ASD) } \\
\text { a. Understanding ASD } \\
\text { b. Characteristics of ASD } \\
\text { c. Causes of ASD } \\
\text { d. Impact of ASD on children and families } \\
\text { e. Life expectancy/future of people with ASD }\end{array}$ \\
\hline 2 & $\begin{array}{l}\text { Social Skills } \\
\text { a. Definition of social skills } \\
\text { b. The importance of social skills in life } \\
\text { c. Types of social skills } \\
\text { d. The importance of eye contact in interacting with other people } \\
\text { e. Types of eye contact } \\
\text { f. How to assess social skills }\end{array}$ \\
\hline 3 & $\begin{array}{l}\text { Intervention } \\
\text { a. Definition of intervention } \\
\text { b. The importance of interventions in dealing with child barriers } \\
\text { c. Types of ASD interventions } \\
\text { d. Critical factors for the success of the intervention } \\
\text { e. The role and function of parents in the intervention } \\
\text { f. Ethics of intervention } \\
\text { g. Eye contact skills intervention techniques }\end{array}$ \\
\hline 4 & $\begin{array}{l}\text { Individual Intervention Programs (IIP) } \\
\text { a. Definition of Individual Intervention Programs } \\
\text { b. The importance of Individual Intervention Programs in dealing with child barriers } \\
\text { c. Elements of an Individual Intervention Program } \\
\text { d. Procedures for developing individual Intervention Programs }\end{array}$ \\
\hline 5 & $\begin{array}{l}\text { Social Skills Individual Intervention Program (SS - IIP) } \\
\text { a. Make a list of the child's strengths and weaknesses in social skills } \\
\text { b. Determine social skills that need to be trained in children } \\
\text { c. Establish clear objectives for the intervention } \\
\text { d. Select intervention equipment according to the child's characteristics and social skills to be } \\
\text { trained } \\
\text { e. Determine the timing of the intervention according to the difficulty level of the social skills to } \\
\text { be trained } \\
\text { f. Determine the place of intervention by the type of social skills to be trained } \\
\text { g. Explain the methods/ways of doing the intervention clearly and the objects/ways to increase } \\
\text { the positive behavior of the child }\end{array}$ \\
\hline
\end{tabular}

For this study, the data were analysed using the Wilcoxon Match Pairs Test non-parametric statistical technique. The test was done under the significance level of $\alpha=0,05$. H0 is rejected if the difference in subjects' ability or skill, before and after receiving the training has the significance level of $\mathrm{p}<0.05$. On the other side, $\mathrm{H} 0$ is accepted if the significance level is $p \geq 0,05$

\section{RESULT AND DISCUSSION}

In this study, parents' skill or ability were based on the result of self-evaluation, using scores ranging from 1-3 (bad/low), 4-6 (decent/medium), and 7-9 (good/high). The data analysis depicts parents' self-evaluation result regarding their comprehension of the ASD, social skills, intervention, Program Intervensi Individual (Individual Intervention Program or IIP) concepts, as well as their skill in designing the Social Skill Individual Intervention Program (SS-IIP) for their children with autism (see Figure 1). 


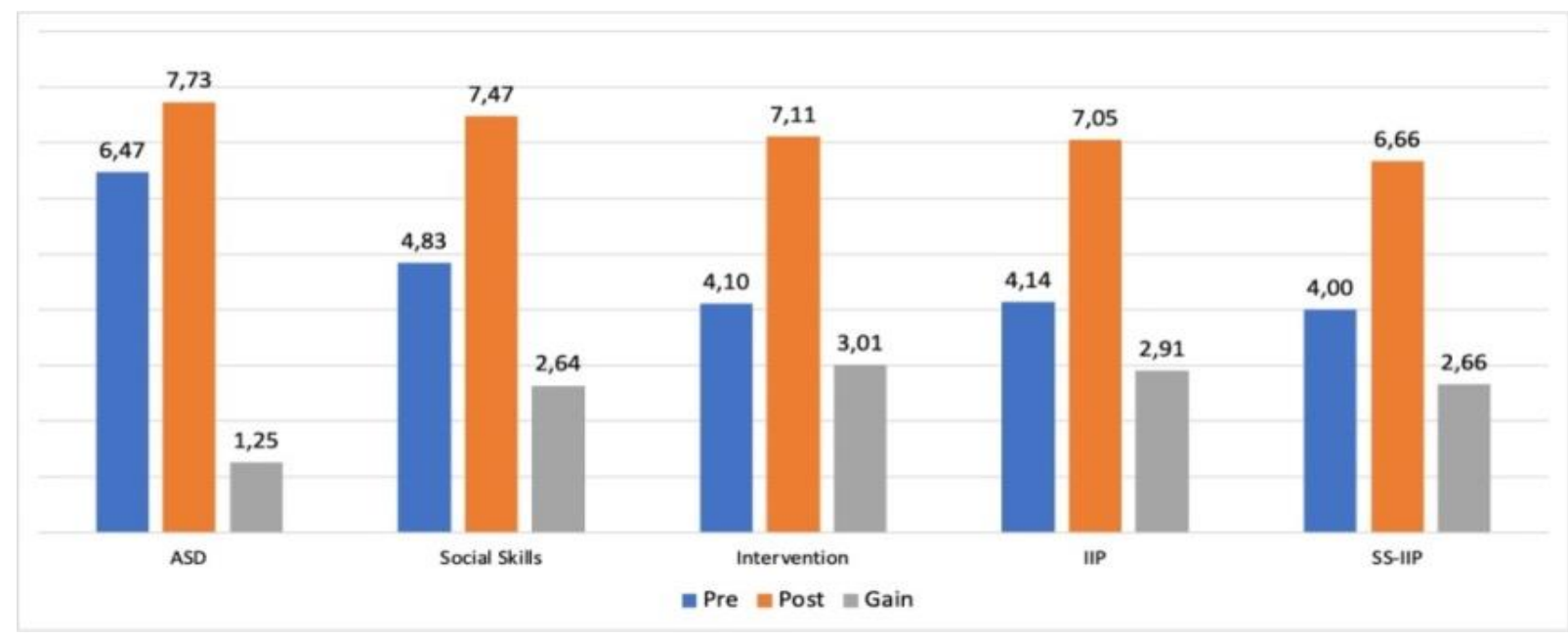

Figure 1. The illustration of subjects' self-evaluation result

Based on figure 1, it is shown that prior the PIM Online Training, parents score the highest in the aspect of understanding concepts related to ASD (ASD mean score $=6.47$ ). This means parents see their comprehension of the ASD concepts as adequate, or even good. This self-evaluation result is understandable, considering the availability of information regarding ASD concepts in an array of media, both academic and popular scientific ones. On the other hand, the parents see their own comprehension of the social skills, intervention, and IIP concepts as decent, despite the scores being close to the lower margin. This implies information regarding such concepts has not been fully comprehended by parents, compared to information related to ASD concepts. The lowest self-evaluation score prior the PIM Online Training belongs to the skill of designing the Social Skill Individual Intervention Program (SS-IIP mean score $=4.00$ ). Parents see their skill in designing the SS-IIP as at the low end of medium categories. This indicates that according to the parents, their skill in designing the individual intervention program for their children with autism is still rather limited.

Observing the assessment following the PIM Online Training, it was found overall score improvement. The highest score belongs to the comprehension of ASD concepts (ASD mean score $=7.73$ ), meaning parents see their own understanding of the concepts after receiving the PIM Online Training as good. Parents' ability or skill in designing the SS-IIP gains the lowest score, with the mean score of 6.66 (the mastery level almost reaches the "good" category). Nevertheless, comparing the mean score margin prior and following the PIM Online Training, it can be observed that the aspect of ASD concepts comprehension gains only 1.25 points, while the score of SS-IIP designing skill gets the additional 2.66 points. This implies that the increase or improvement in subjects' SS-IIP designing skill after receiving the PIM Online Training is more significant compared to the subjects' improvement in terms of understanding the ASD concepts. The same applies to subjects' comprehension of the social skills, intervention, and IIP concepts after the PIM Online Training. Despite the mean score of such aspects being lower than the mean score of the aspects of ASD concepts comprehension, the improvement or increase of the three aforementioned concepts is more significant. The significance test result on the difference in parents' skill or ability, prior and following the PIM Online Training can be seen in Table 2.

Table 2. The significance test result on parents' skill or ability, prior and following the PIM Online Training

\begin{tabular}{lrrrrr}
\hline & $\begin{array}{c}\text { Post ASD - Pre } \\
\text { ASD }\end{array}$ & $\begin{array}{c}\text { Post Soc.Skills } \\
\text { - Pre Soc. } \\
\text { Skills }\end{array}$ & $\begin{array}{c}\text { Post Interv - } \\
\text { Pre Interv. }\end{array}$ & \multicolumn{1}{c}{$\begin{array}{c}\text { Post IIP - Pre } \\
\text { IIP }\end{array}$} & $\begin{array}{c}\text { Post SS-IIP - } \\
\text { Pre SS-IIP }\end{array}$ \\
\hline $\mathrm{Z}$ & $-2.558^{\mathrm{a}}$ & $-2.848^{\mathrm{a}}$ & $-2.762^{\mathrm{a}}$ & $-2.810^{\mathrm{a}}$ & $-2.934^{\mathrm{a}}$ \\
$\begin{array}{l}\text { Asymp. Sig. } \\
\text { (2-tailed) }\end{array}$ & .011 & .004 & .006 & .005 & .003 \\
\hline
\end{tabular}

Based on table 2, it is shown that there is a significant difference in parents' comprehension of ASD, social skills, intervention, and IIP concepts, as well as their skill in designing the SS-IIP, before and after receiving the PIM Online Training ( $\mathrm{p}<0.05$ ). It can be assumed that the PIM Online Training has successfully improved parents' skill in comprehending the trained concepts, as well designing the SS-IIP. Based on figure 1, 
it can be seen that the ASD score from online training participants gained an average score $=6.47$. From these results, it can be exposed that the participants have understood the concept of ASD based on what is listed in the grid. Some of these aspects include (1) Understanding ASD, (2) Characteristics of ASD, (3) Causes of ASD, (4) Impact of ASD on children and families, and (5) Life expectancy / future of people with ASD. This supports the statement of online programs that can be self-determined and directed to obtain support for information and training about children with autism (Suppo \& Mayton, 2014) as well as training meets the needs of parents and has elements which are tailored to the needs of certain families, will give a positive impact for parents when intervening in their children (Booth et al., 2018).

The second dimension is social skills. Referring to the figure 1 , even though the gained scores were close to a low margin, the parents of these trainees felt that the ability to understand social skills was something they deserved. This is obtained based on the aspects listed in the grid consisting of (1) Definition of social skills, (2) The importance of social skills in life, (3) Types of social skills, (4) The importance of eye contact in interacting with other people, (5) Types of eye contact, (6) How to assess social skills. Social skills are needed because the ability to understand social skills (including communication) can increase the use of intervention techniques, especially for children with autism (Ingersoll \& Wainer, 2013). Intervention is essential. Based on what is depicted in figure 1 , it can be seen that the ability to understand the intervention is feasible even though the score is approaching a lower margin. It is based on the aspects listed in the outlines, namely (1) Definition of intervention, (2) The importance of interventions in dealing with child barriers, (3) Types of ASD interventions, (4) Critical factors for the success of the intervention (5) The role and function of parents in the intervention, (6) Ethics of intervention, and (7) Eye contact skills intervention techniques. This supports the theory that parents' understanding of intervention is important (Rafikayati \& Jauhari, 2018). It can affect the effectiveness of interventions carried out by parents to reduce the severity of autism (Oono et al., 2013) and increase the accuracy of intervention technique used (Ingersoll \& Wainer, 2013).

The IIP concept was also considered a worthy acquisition according to the participants even though the score was close to a lower margin. It is shown on the aspects listed in the outlines consisting of (1) Definition of Individual Intervention Programs, (2) The importance of Individual Intervention Programs in dealing with child barriers (3) Elements of an Individual Intervention Program, and (4) Procedures for developing individual Intervention Programs. Finally, the SS-IIP concept gained the lowest score (mean SS-IIP score $=4.00$ ). It shows that the existing aspects in the outlines consisting of (1) Make a list of the child's strengths and weaknesses in social skills, (2) Determine social skills that need to be trained in children, (3) Establish clear objectives for the intervention, (4) Select intervention equipment according to the child's characteristics and social skills to be trained, (5) Determine the timing of the intervention according to the difficulty level of the social skills to be trained, (6) Determine the place of intervention by the type of social skills to be trained, and (7) Explain the methods / ways of doing the intervention clearly and the objects / ways to increase the positive behavior of the child. These results indicate that according to parents, skills in designing individual intervention programs for children with autism are still somewhat limited. It can lead to inadequate handling by parents of children with autism so that trainings can hopefully be carried out (Irvan, 2016). Parents who have high SS-IIP abilities will actually help improve the development of children with autism (Yuwono et al., 2020).

Overall, the data analysis result described in Figure 1 shows that parents' ability or skill in conceptual aspects (comprehension of ASD, social skills, intervention, and IIP concepts) before having PIM Online training is better, compared to their skill in designing the SS-IIP. Parents' skill in designing the SS-IIP being limited is in line with the result of the study conducted by Dunst et al., (2014), showing that in intervention programs performed on the children, parents are only trained to implement the professional-designed intervention program. Parents are not trained to design their own intervention program for their children. It is in line with the statement that training to meet parents' needs and provide elements tailored to the needs of certain families will have a positive impact on parents when intervening their children (Booth et al., 2018). It clearly shows that intervention training programs for parents should include materials regarding the practice of designing an individual intervention programs which, later, can be used by parents as a reference to intervene in their children. The test result of the difference in parents' skill or ability — both conceptual and practical—prior and following the PIM Online Training shows some significant improvement (Table 2).

\section{CONCLUSION}

There are five dimensions used for the assessment of this PIM Online Training. The five dimensions show different average score results. The concept of ASD has the highest average score where from these results it can be interpreted that most of the parents of the PIM training participants have a good and adequate ability to understand the concept of ASD. On the other hand, the understanding of the PIM training participants' parents regarding social skills, interventions, and the IIP concept was considered adequate even though the score was close to a lower margin, while the SS-IIP concept received the lowest score because according to the parents of 
the PIM trainees who skills in designing programs individual interventions for children with autism are somewhat limited. PIM Online Training has successfully empowered parents of children with autism. Although there are dimensions by a low score, overall this PIM Online Training has succeeded in improving the skills of parents to deal with children with autism.

\section{REFERENCES}

Allen, A. A., \& Shane, H. C. (2014). Autism Spectrum Disorders in the Era of Mobile Technologies: impact on caregivers. Developmental Neurorehabilitation, $\quad$ 17(2), 110-114. https://doi.org/10.3109/17518423.2014.882425.

Autism Ontario. (2012). What to Look for When Choosing Social Skills Programs for People with ASD. Social Matters: Improving Social Skills Intervention for Ontarians with ASD.

Beaudoin, A. J., Sébire, G., \& Couture, M. (2014). Parent Training Interventions for Toddlers with Autism Spectrum Disorder. Autism Research and Treatment, 2014, 1-15. https://doi.org/10.1155/2014/839890.

Booth, N., Gallagher, S., \& Keenan, M. (2018). Autism, Interventions and Parent Training. Psichologija, 57(2018), 74-94. https://doi.org/10.15388/Psichol.2018.0.11904.

Douglas, S. N., Nordquist, E., Kammes, R., \& Gerde, H. (2017). Online Parent Training to Support Children with Complex Communication Needs. Infants and Young Children, 30(4), 288-303. https://doi.org/10.1097/IYC.0000000000000101.

Dunst, C. J., Bruder, M. B., \& Espe-Sherwindt, M. (2014). Family Capacity-Building in Early Childhood Intervention: Do Context and Setting Matter? School Community Journal, 24(1), 37-49.

Elder, J. (2013). Empowering Families in the Treatment of Autism. In Recent Advances in Autism Spectrum Disorders - Volume I. InTech. https://doi.org/10.5772/54303.

Ilias, K., Liaw, J. H. J., Cornish, K., Park, M. S.-A., \& Golden, K. J. (2017). Wellbeing of mothers of children with "A-U-T-I-S-M" in Malaysia: An interpretative phenomenological analysis study. Journal of $\begin{array}{lllll}\text { Intellectual \& Developmental } & \text { Disability, }\end{array}$ https://doi.org/10.3109/13668250.2016.1196657.

Ingersoll, B., \& Wainer, A. (2013). Initial Efficacy of Project ImPACT: A Parent-Mediated Social Communication Intervention for Young Children with ASD. Journal of Autism and Developmental Disorders, 43(12), 2943-2952. https://doi.org/10.1007/s10803-013-1840-9.

Ingersoll, B., Wainer, A. L., Berger, N. I., Pickard, K. E., \& Bonter, N. (2016). Comparison of a Self-Directed and Therapist-Assisted Telehealth Parent-Mediated Intervention for Children with ASD: A Pilot RCT. Journal of Autism and Developmental Disorders, 46(7), 2275-2284. https://doi.org/10.1007/s10803016-2755-z.

Irvan, M. (2016). Pengetahuan Orang Tua, Guru, dan Terapis tentang Anak Autism Spectrum Disorder. HELPER : Jurnal Bimbingan Dan Konseling, 32(2). https://doi.org/10.36456/helper.vol32.no2.a466.

Iswari, M., Kasiyati, K., Zulmiyetri, Z., \& Hasan, Y. (2019). Training Increases Understanding of Teachers and Parents About Healthy Food for Children with Autism. Jurnal Aplikasi IPTEK Indonesia, 3(3), 116120. https://doi.org/10.24036/4.1296.

Karst, J. S., \& Van Hecke, A. V. (2012). Parent and Family Impact of Autism Spectrum Disorders: A Review and Proposed Model for Intervention Evaluation. Clinical Child and Family Psychology Review, 15(3), 247-277. https://doi.org/10.1007/s10567-012-0119-6.

Kasari, C., Gulsrud, A., Paparella, T., Hellemann, G., \& Berry, K. (2015). Randomized Comparative Efficacy Study of Parent-Mediated Interventions for Toddlers with Autism. Journal of Consulting and Clinical Psychology, 83(3), 554-563. https://doi.org/10.1037/a0039080.

Kolb, M. J. (2007). An Online Training Program for Parents of Children with Autism. University of Maryland.

Kuravackel, G. M., Ruble, L. A., Reese, R. J., Ables, A. P., Rodgers, A. D., \& Toland, M. D. (2018). COMPASS for Hope: Evaluating the Effectiveness of a Parent Training and Support Program for Children with ASD. Journal of Autism and Developmental Disorders, 48(2), 404-416. https://doi.org/10.1007/s10803017-3333-8.

Kurniadi, G., Atmodiwirjo, E. T., \& Soetikno, N. (2019). Hubungan Antara Harapan Dan Stres Orang Tua Yang Memiliki Anak Dengan Autisme. Jurnal Muara Ilmu Sosial, Humaniora, Dan Seni, 3(2), 358. https://doi.org/10.24912/jmishumsen.v3i2.3860.

Murray, M., Handyside, L., Straka, L., \& Arton-Titus, T. (2013). Parent empowerment: connecting with preservice special education teachers. School Community Journal, 23(1), 145-168.

Negri, L. M., \& Castorina, L. L. (2014). Family Adaptation to a Diagnosis of Autism Spectrum Disorder. In J. Tarbox, D. R. Dixon, P. Sturmey, \& J. L. Matson (Eds.), Handbook of Early Intervention for Autism Spectrum Disorders. Springer New York. https://doi.org/10.1007/978-1-4939-0401-3. 
Oono, I. P., Honey, E. J., \& Mcconachie, H. (2013). Parent-mediated early intervention for young children with autism spectrum disorders (ASD). Cochrane Database of Systematic Reviews, 2013(4). https://doi.org/10.1002/14651858.CD009774.pub2.

Patricia, K. G., Fumio, J. B., Rita, S., Steven, C. S., Nidal, K. K., David, D., \& Smith, S. (2015). Changing College Students' Conceptions of Autism: An Online Training to Increase Knowledge and Decrease Stigma. Journal of Autism and Developmental Disorders, 45, 2553-2566. https://doi.org/10.1007/s10803-015-2422-9.

Patterson, S. Y., Smith, V., \& Mirenda, P. (2012). A systematic review of training programs for parents of children with autism spectrum disorders: Single subject contributions. Autism, 16(5), 498-522. https://doi.org/10.1177/1362361311413398.

Pennefather, J., Hieneman, M., Raulston, T. J., \& Caraway, N. (2018). Evaluation of an Online Training Program to Improve Family Routines, Parental Well-Being, and the Behavior of Children with Autism. Research in Autism Spectrum Disorders, 54, 21-26. https://doi.org/10.1016/j.rasd.2018.06.006.

Pillay, M., Alderson-Day, B., Wright, B., Williams, C., \& Urwin, B. (2011). Autism Spectrum Conditions Enhancing Nurture and Development (ASCEND): An evaluation of intervention support groups for parents. Clinical Child Psychology and Psychiatry, 16(1), 5-20. https://doi.org/10.1177/1359104509340945.

Primasari, I. F. N. D., \& Supena, A. (2020). Peran Orang Tua Anak Berkebutuhan Khusus (Autis) Sekolah Dasar Selama Masa Covid-19. JS (Jurnal Sekolah), 5(1), 133-142. https://doi.org/10.24114/js.v5i1.23309.

Putri, A. M., Pramesti, W., \& Hapsari, R. D. (2019). Stres Pada Orang Tua Yang Memiliki Anak Dengan Gangguan Spektrum Autisme. Jurnal Psikologi Malahayati, 1(1), $7-13$. https://doi.org/10.33024/jpm.v1i1.1408.

Rafikayati, A., \& Jauhari, M. N. (2018). Keterlibatan Orangtua dalam Penanganan Anak Berkebutuhan Khusus. Jurnal Abadimas Adi Buana, 2(1), 55-64. https://doi.org/10.36456/abadimas.v2.i1.a1636.

Rudy, L. J. (2013). Should Parents Provide Their Own Children's Autism Therapy?

Schultz, T. R., Schmidt, C. T., \& Stichter, J. P. (2011). A review of parent education programs for parents of children with autism spectrum disorders. Focus on Autism and Other Developmental Disabilities, 26(2), 96-104. https://doi.org/10.1177/1088357610397346.

Steiner, A. M., Koegel, L. K., Koegel, R. L., \& Ence, W. A. (2012). Issues and Theoretical Constructs Regarding Parent Education for Autism Spectrum Disorders. Journal of Autism and Developmental Disorders, 42(6), 1218-1227. https://doi.org/10.1007/s10803-011-1194-0.

Suppo, J. L., \& Mayton, M. R. (2014). Expanding Training Opportunities for Parents of Children with Autism. Rural Special Education Quarterly, 33(3), 226. https://doi.org/10.1177/875687051403300304.

Susilana, R., Herlina, \& Hadiapurwa, A. (2020). Pengembangan Website Pelatihan Program Intervensi Mandiri (PIM()) bagi Orangtua Anak Penyandang Autisme. Pedagogia Jurnal Ilmu Pendidikan, 18(02), 173187. https://doi.org/10.17509/pdgia.v18i2.31424.

Tirtayani, L. A., Magta, M., \& Lestari, N. G. A. M. Y. L. (2017). Teacher Friendly e-Flashcard: a development of bilingual learning media for young learners. Journal of Education Technology., 1(1), 18-29. http://dx.doi.org/10.23887/jet.v1i1.10080.

Yuwono, J., Martika, T., \& Anggrellanggi, A. (2020). Parental Competencies in Providing Services for the Development of Autistic Children. Jurnal Exponential (Education for Exceptional Children) Jurnal Pendidikan Luar Biasa, 1(2), 181-193.

Zorzi, S., \& Marzano, G. (2020). Parent-Training to Support Parents of Children with Autism Spectrum Disordes. Society. Integration. Education. Proceedings of the International Scientific Conference, 4, 177-186. https://doi.org/10.17770/sie2020vol4.4834. 